Girshfeld A., Simson E.

\title{
DEVELOPMENT AND OPTIMIZATION OF TECHNOLOGY AND MODERNIZATION OF FORGING LINE FOR BEARING RINGS
}

Об’єктом дослідження є ковальська лінія Л-408 (Україна) для виробництва заготовок кілець залізничних підшипників. Ця лінія встановлена на Харківському підшипниковому заводі (Акціонерне Товариство «ХАРП», Україна) та складається з ділянки індукційного розігріву КІН 750, гідравлічного три-позиційного преса П-2038А та кільце-розкочувальної установки КПС 250. За результатами технічного аудиту лінії виявлено, що КІН 750 було вироблено на застарілій апаратній базі й він має більш низъкий ККД. Крім того, відсутність можливостей управління потужністю та частотою в процесі розігріву не дає можливості оптимізувати процес за витратами електроенергї. Також преси всіх шістьох ліній працюють від однієі гідравлічної насосної станції, що викликає ї̈ свідомо неефективну роботу при використанні лише частини лінії. Окрім того, принщип роботи преса П-2038А за відсутністю системи управління гідравлічним тиском у виконавчих органах преса не дозволяє реалізувати оптимальне управління гідронасосами за критерієм мінімуму електроенергї, що споживається.

В ході дослідження основним методом математичного моделювання індукційного нагріву заготовки та ковальських операцій обрано метод скінчених елементів. Розроблена й виготовлена нова система індукційного нагріву має безсумнівні переваги перед існуючою раніше лінією індукційного нагріву, оскільки виконана на сучасній елементній базі й має можливості програмного управління потужністю в процесі нагріву. Виконана модернізащія преса з автономною насосною станщією потужністю $132 \mathrm{KBm}$ (замість центральної станиї потужністю $900 \mathrm{KBm}$ ). Використання кінетичної енергї повзуна й траверс надає радикального зниження енергоспоживання, особливо в умовах роботи декількох або тим більш однієї з шести ковальських ліній Л-408.

Математичні моделі й численні методи, розроблені для моделювання керованого індукиійного розігріву заготовок та об'ємно-пресових операцій, довели свою ефективність при розрахунку й оптимізацї конструктивних та режимних параметрів гаряче-ковальської лінії. Отримані за допомогою математичного моделювання ефекти повністю були підтверджені при натурних випробуваннях, а власне значення температур та тиску незначним чином відрізнялись від результатів вимірів.

Ключові слова: індукційний нагрів, гідравлічний прес, гаряча формовка, взаємопов'язана мульти-фізічна задача, термопластичне деформування, метод кінцевих елементів.

\section{Introduction}

Bearings throughout the development of civilization have been and remain the most common components of the vast majority of machines and mechanisms. Because of this, the production of bearings is rightly considered a strategic industry. Joint-Stock Company Kharkiv Bearing Plant (JSC HARP, Ukraine) is the largest manufacturer of a wide range of bearings for rail and road transport, agricultural machinery, machine tools and other engineering industries. In the past, JSC HARP (GPZ No. 8 - «8th State Bearing Plant») was the main enterprise in the Soviet bearing industry for the All-Union Bearing Research Institute (VNIPP) in the development of new types of bearings and new serial production technologies.

One of the most important production areas in the production of bearings is the forging line L-408 (Ukraine) for the production of ring workpieces. First, the workpieces enter the induction heating line, then into the hydraulic press, and finally, at the end of the line, the ring is hot rolled. According to the results of the technical audit, it is revealed that in the current market situation, characterized by a much larger nomenclature of bearing rings and smaller volumes of produced batches, such a configuration of production leads to huge unjustified energy costs. Thus, there is a need for a radical modernization of the forging production aimed at ensuring the autonomous operation of each forging line and, at the same time, modernization of the design of induction heating units and a hydraulic press, which, thanks to new technologies, provide higher efficiency and, at the same time, quality of the workpieces themselves.

This work outlines the main stages of the original theoretical and field studies, which provided the development of a new line. The studies are carried out in the Joint Engineering Center (JEC) of the UPEC Industrial Group (Ukrainian Industrial Energy Company, which includes JSC HARP) and have independent scientific value in solving similar problems of modernizing blacksmith production. 


\section{The object of research and its technological audit}

The object of research is the forging line $\mathrm{L}-408$ for the production of workpieces for rings of railway bearings (Fig. 1). The line consists of:

- the induction heating section of KIN 750 produced by the All-Union Scientific Research and Design Institute of High Frequency Currents (VNIITVCH, Leningrad, USSR);

- hydraulic three-position press P-2038A produced by Dnipropress (Dnipro, Ukraine) with operations «upsetting», «shaping», «punching»;

- ring-rolling mills KPS 250 produced by Starokramatorsk Machine-Building Plant (Ukraine).

The study focused on the first two sites, which are the main sources of energy loss.

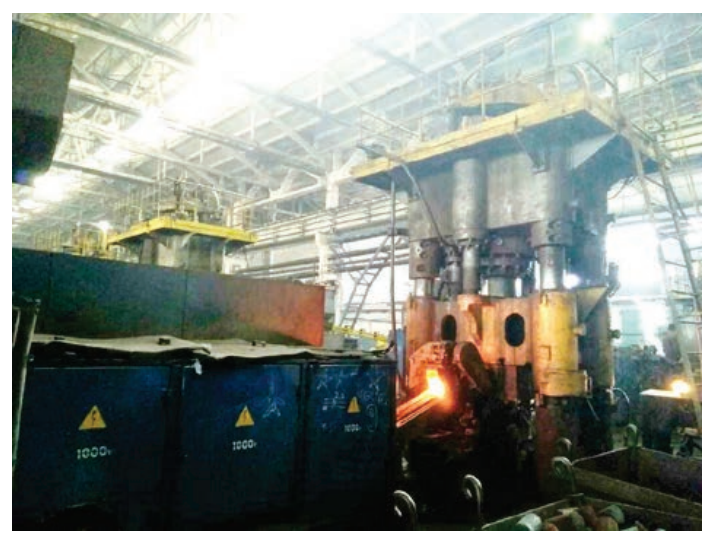

a

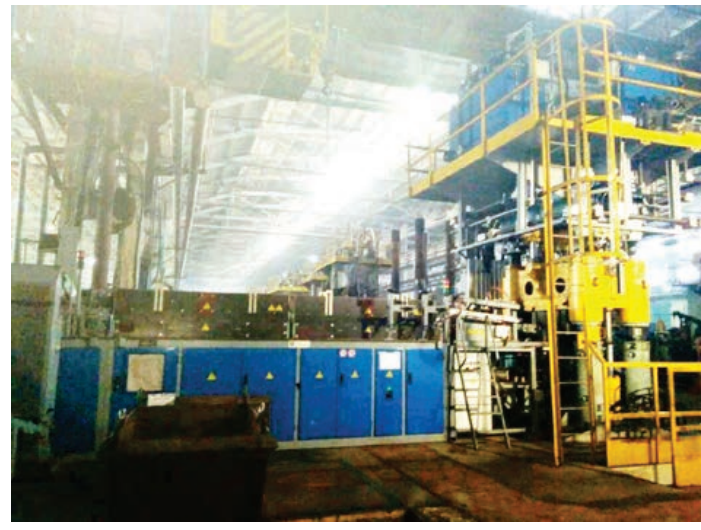

$b$

Fig. 1. General view of the forging line L-408: $a$ - old; $b$ - modernized

There are six such lines at the plant and they are the largest consumers of electricity both in the areas of induction heating and in the hydraulic pump station, which ensures the operation of all presses. The plant itself and, accordingly, the forging workshop, were created for the mass production of a small range of bearing rings and, due to this, the lines were combined into a system with unified electric and hydraulic stations that ensure the operation of all forging lines.

According to the results of a technical audit conducted by UPEC JEC, it is revealed that in the current market situation, characterized by a much larger nomenclature of bearing ring types, but smaller volumes of each type of production, such a configuration of equipment leads to huge unjustified energy costs.

It is also revealed that KIN 750 is produced on an outdated hardware base, powered by an electric machine converter, in contrast to modern systems operating on a semiconductor base. An electric machine converter that provides the conversion of electricity from the factory power supply network to a power signal with a frequency of up to $1.000 \mathrm{~Hz}$ already due to its electromechanical principle of operation has additional mechanical losses and, as a result, a deliberately lower efficiency (not more than 90-94\%). In addition, the fundamental lack of power and frequency control capabilities during the heating process does not make it possible to optimize the process for energy costs. This leads to additional losses, which can only be estimated by designing a KIN (induction heating units) on a new element base with a modern control system based on a PLC (programmable logic controller) and making such a comparison first by mathematical, and then, full-scale, physical modeling.

As a result of a technical audit of P-2038A hydraulic press, it is found that the presses of all six lines operate from one hydraulic pump station. This provokes its obviously inefficient work when only part of the lines are involved, and sometimes even one line at all.

In addition, the principle of operation of the P-2038A press in the absence of a hydraulic pressure control system in the press executive bodies does not allow optimal control of hydraulic pumps to be implemented according to the criterion of minimum electric power consumption.

\section{The aim and objectives of research}

The aim of this research is to develop a project for deep modernization of the forging line, based on mathematical modeling and optimization of induction heating processes and forging operations.

To achieve this aim it is necessary to solve the following objectives:

1. Development of a mathematical model of induction heating of workpieces, as well as operations of upsetting, shaping and punching.

2. Development of the basic design of modernized line.

3. Optimization of technological modes on mathematical models and field experiments.

\section{Research of existing solutions of the problem}

Induction heating, using the induction interaction of the electromagnetic field of high and medium frequency currents with a metal workpiece, has been known and used in industry for over 100 years for induction heating, induction melting, induction hardening and induction welding of metals. The fundamentals of engineering calculations of induction heating systems are described in sufficient detail in [1]. A quantitative and qualitative description of the interaction of physical processes occurring in a workpiece from ferromagnetic steel, which ultimately leads to its heating, is largely devoted to [2]. In [3], a systematic refinement of mathematical modeling of induction heating based on the finite element method is considered, including specific issues of using the ANSYS complex in modeling induction heating and induction hardening processes. The 
study [4] refines the behavior of carbon steels in modeling induction hardening. In [5], the results of a test study of induction heating of a cylindrical workpiece of a bearing ring based on the finished element method in the relationship of Maxwell's equations and the heat conduction problem are presented. A similar mathematical model of interconnected electromagnetic and thermal processes for axisymmetric workpieces was considered in [6]. In [7], specific issues of modeling surface induction hardening by high-frequency currents are considered. The finite element method is undoubtedly the main tool for numerical modeling of induction hardening technology, but not the only one. So, in [8], the features of numerical modeling of induction hardening processes for two-dimensional axisymmetric workpieces (cylindrical objects) were considered using the boundary element method (BEM).

In [9], a technique for evaluating and optimizing the forging process using modern computer tools for developing a product model, associated equipment, as well as subsequent modeling and analysis of deformation processes is presented. The problems of modeling by finite element methods of both cold and hot stamping processes are quite fully described in [10]. The statement of the associated problem of induction heating and plastic deformation of a cylindrical workpiece was considered by the authors in [11]. Mathematical modeling of pressure treatment of axisymmetric (cylindrical) parts during three-stage shaping is considered in [12]. The methodology for modeling wear of die tooling taking into account the thermal effect on the material of the die is described in [13]. Additionally, the analysis of thermomechanical deformations of stamping equipment during hot stamping is considered in [14]. The work [15] addresses the issues of mathematical modeling of the optimal design of a hydraulic press taking into account variable loads.

Thus, the analysis allows to conclude that the finite element method is applicable for modeling the process of induction heating of cylindrical workpieces. It can also be used to simulate plastic deformation processes during hot stamping. It can also be said that there is a number of works on mathematical modeling of the optimal design of hydraulic presses, but there is no scientific work combining the modeling of the entire process of manufacturing a ring forging with a view to further optimization.

\section{Methods of research}

The finite element method is chosen as the main method of mathematical modeling of induction heating of the workpiece, as well as forging operations.

5.1. Mathematical modeling of induction heating of a workpiece. The main task of induction heating unit is to heat the workpiece ring to the temperature necessary and sufficient for forging operations in the press. This target temperature, according to many years of experience in operating existing forging lines, should not be lower than $1120{ }^{\circ} \mathrm{C}$, otherwise the shaping operation will not be of high quality and the ring will lose temperature before hot rolling mill. At the same time, this temperature can't be higher than $1180{ }^{\circ} \mathrm{C}$, since taking into account the instability of heating, this can lead to irreversible metallurgical changes in the structure of steel (burn out). The instability of temperature from the workpiece to the workpiece should not exceed $\pm 20{ }^{\circ} \mathrm{C}$. And the uneven heating of the workpiece itself in the volume of material (between the outer layers and the core) should not exceed $50{ }^{\circ} \mathrm{C}$.

The multi-physical mathematical model adopted in the simulation of induction heating of a cylindrical workpiece consists of interconnected systems of Maxwell equations for describing the electromagnetic field and non-stationary Fourier heat equations with the corresponding boundary and initial conditions:

$$
\begin{aligned}
& \operatorname{rot} H=\sigma(H) E+\varepsilon \frac{\partial E}{\partial t} ; \\
& \operatorname{rot} E=-\frac{\partial B}{\partial t}=-\mu(T) \frac{\partial H}{\partial t} ; \\
& j=\sigma(T) E+\frac{\partial D}{\partial t} ; \\
& \rho C(T) \frac{\partial T}{\partial t}=\operatorname{div}(\lambda(T) \operatorname{grad} T)+Q(t)+p(t),
\end{aligned}
$$

where $H$ - the magnetic field strength; $E$ - the electric field strength; $B$ - magnetic induction; $J$ - the current density; $D$ - the electric induction; $\sigma(T)$ - the electrical conductivity, $\mu(T)$ - the magnetic permeability, $C(T)$ - the heat capacity, and $\lambda(T)$ - the heat conductivity of the metal, which in turn is nonlinearly dependent on temperature $T$.

The distribution of current density $j_{r}$ along the radius (depth) is taken in the form:

$$
j_{r}=j_{0} e^{k r},
$$

and the penetration depth of electromagnetic radiation $\delta$ (skin layer depth) is defined as:

$$
\sigma=\sqrt{\frac{2 \rho_{e}}{\omega \mu_{0} \mu}},
$$

where $\omega-$ the angular frequency; $\rho_{e}-$ the resistivity of the workpiece material; $\mu_{0}$ - vacuum permeability; $\mu$ - the specific permeability of the workpiece material.

The density distribution of heat sources is described by the formula:

$$
p(t)=\sigma(T) E^{2}(t)=\frac{1}{\sigma(T)} j^{2}(t) .
$$

Additional heat in carbon steels occurs during the transformation of the material structure from pearlite to austenitic, while the density of the sources of which can be defined as:

$$
Q=\rho L \frac{\partial \psi}{\partial t}
$$

$\rho$ - the density; $L$ - the bulk density of the heat source; $\Psi-$ the volume fraction of transformed austenite.

The boundary conditions of heat transfer on the cylindrical surface of the workpiece are taken in the form:

$$
\pm\left.\lambda \frac{\partial T}{\partial n}\right|_{s u r}=\alpha_{k}\left(T_{s u r}-T_{a m b}\right)+\sigma_{t}\left(T_{s u r}^{4}-T_{a m b}^{4}\right),
$$

where $\alpha_{k}$ - the convective heat transfer coefficient; $\sigma_{t}$ - heat transfer coefficient by radiation; $T_{\text {sur }}$ - surface temperature; $T_{a m b}$ - ambient temperature. 
Earlier [5], test finite element (FE) calculations and optimization of the induction heating of a cylindrical workpiece made of ShKh15 steel with a length of $L=190 \mathrm{~mm}$ and a radius $r=50 \mathrm{~mm}$ of a two-section cylindrical inductor with a current frequency of $f=800 \mathrm{~Hz}$ are performed. The mathematical model of the workpiece included more than 60,000 finite elements. Fig. 2 shows the graphs used in the calculation of the dependences of the physical characteristics of ShKh15 steel on temperature. Fig. 3 shows the calculated FE-diagram of the inductor with the workpiece.
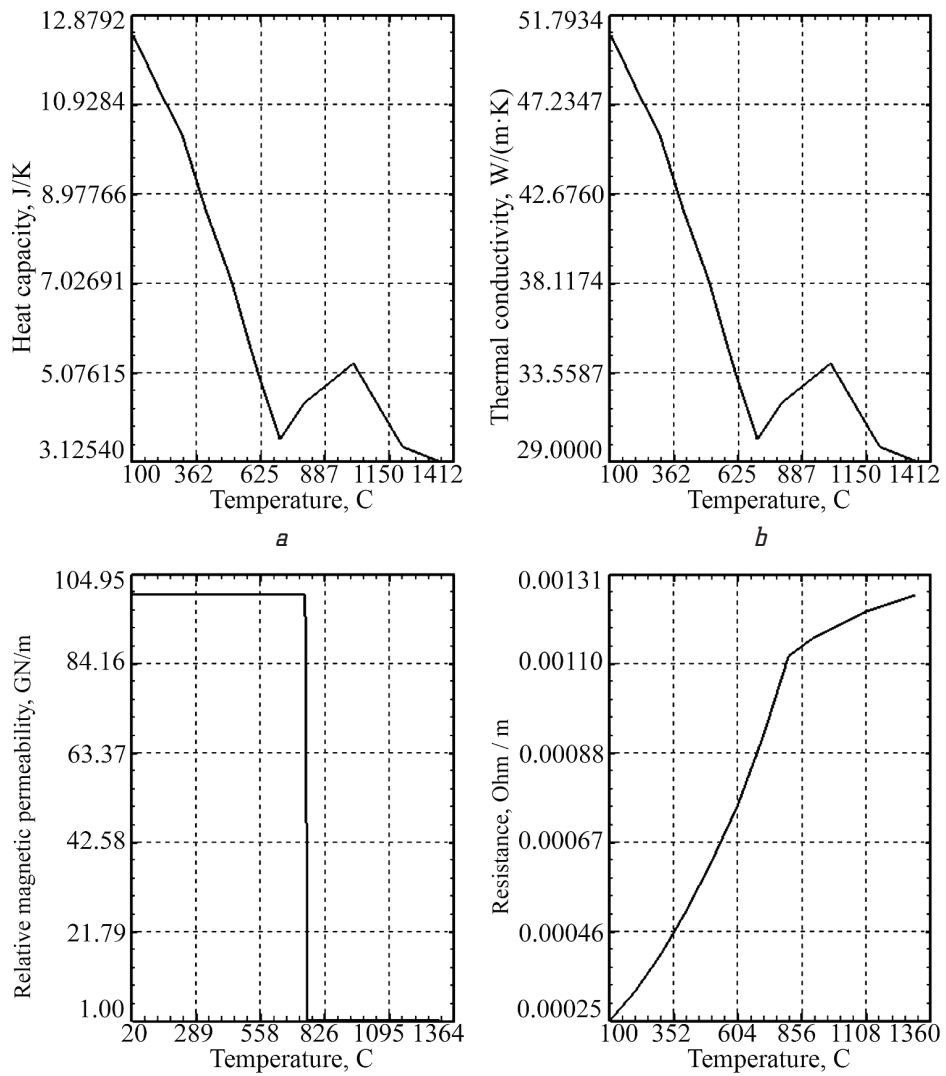

c boundary conditions reflect the model of radiant and convective heat exchange with air on all surfaces of the workpiece). Since the heating control in the future automatic system will be carried out by pyrometers measuring the temperature on the surface of the workpiece, this effect can lead to erroneous overheating of the inner layers of steel, which should be taken into account when programming the KIN control system.

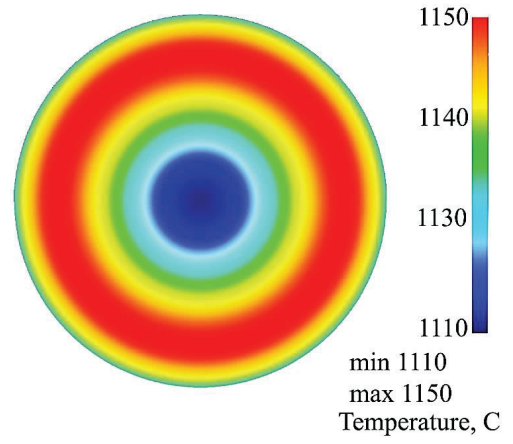

Fig. 4. The results of model calculations

To proceed to the next technological operation - stamping the ring, it is necessary to solve the problem of cooling the workpiece in the form of an unsteady heat conduction problem, taking into account the temperature field obtained after heating. Fig. 5 shows the temperature field of the workpiece after cooling for $t=5 \mathrm{~s}$, which represents the average time the workpiece arrived from the induction heating unit (KIN) before the first forging operation in the press upsetting.

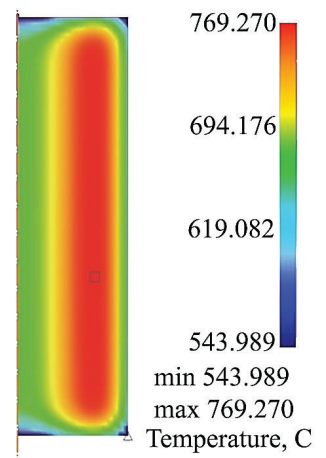

Fig. 5. The temperature field of the workpiece after cooling for 5 seconds

5.2. Mathematical modeling of workpiece volumetric stamping. To analyze the technological process of volumetric stamping of the bearing ring, let's use a mathematical model of a coupled nonlinear thermo-visco-plastic contact problem that takes into account nonlinear physical and geometric relationships (taking into account large deformations and strain rates):

$$
\begin{aligned}
& \dot{\rho}=-\frac{\partial v_{i}}{\partial x_{i}}, \\
& \rho \dot{e}=\sigma_{i j} \frac{\partial v_{i}}{\partial x_{j}}+\rho r-\frac{\partial q_{i}}{\partial x_{j}}, \\
& \rho \dot{v}_{i}=\frac{\partial \sigma_{i j}}{\partial x_{j}}+\rho f_{i}^{B},
\end{aligned}
$$


where $\rho, \dot{\rho}-$ density and density change rate; $v_{i}, \dot{v}_{i}-$ speed and acceleration; $e=e(\rho, T)$ - the specific internal energy; $\sigma_{i j}$ - the stress tensor; $r$ - internal distributed heat sources; $q_{i}$ - the components of the heat flux vector; $f_{i}^{B}$ - the components of the vector of volume forces; $T$ - temperature.

In this case, the physical equations are taken in the form:

$$
\begin{aligned}
& \sigma_{i j}^{T}=C_{i j k l} D_{k l}, \\
& \sigma_{i j}^{T}=\sigma_{i j}+\frac{\partial v_{k}}{\partial x_{k}} \sigma_{i j}-\frac{\partial v_{i}}{\partial x_{k}} \sigma_{j k}-\frac{\partial v_{j}}{\partial x_{k}} \sigma_{i k}, \\
& D_{k l}=\frac{1}{2}\left(\frac{\partial v_{k}}{\partial x_{l}}+\frac{\partial v_{l}}{\partial x_{k}}\right),
\end{aligned}
$$

where $\sigma_{i j}$ - the stress velocity tensor; $C_{i j k l}$ - tensor of the physical law of «stress-strain»; $D_{k l}$ - strain rate tensor for large plastic strains, including plastic and temperature components:

$$
D_{i j}=D_{i j}^{p}+D_{i j}^{T},
$$

In this case, plastic deformation is described by the theory of flow in a velocity form:

$$
D_{i j}^{p}=\dot{\lambda} \frac{\partial F}{\partial \sigma_{i j}},
$$

where $\lambda$ - the plasticity parameter; $F$ - the plastic potential, determined in the calculations as:

$$
F\left(\sigma_{i j}, \sigma_{y}\right)=f\left(\sigma_{i j}\right)-\sigma_{y},
$$

where $\sigma_{y}$ - the functional dependence for the current yield strength; $f\left(\sigma_{i j}\right)$ - the plasticity function. Naturally, the dependence of the physicomechanical properties of the material on the level of temperatures and strain rates, which is characteristic of high-speed and high-temperature deformation, is taken into account.

The contact problem is solved taking into account slippage:

$$
\begin{aligned}
& \left|\tau_{i}\right| \leq \mu_{s}\left|p_{n}\right| \\
& f_{c n}^{l}=H^{l} f_{c n}^{K}, \\
& f_{c n}^{J}=H^{J} f_{c n}^{K},
\end{aligned}
$$

where $p_{n}=\sigma_{n}=f_{c n}$ - the contact pressure, and $\tau_{t}=f_{c t}-$ the tangential force at the contact point; $\mu_{S}$ - the coefficient of friction.

Of course, in parallel, the interconnected problem of unsteady heat conduction is solved with the corresponding boundary conditions of convective heat transfer on the free surfaces of the matrix and taking into account contact heat transfer in the contact zones of the workpiece-matrix and punch-workpiece.

Earlier, to verify the model, test calculations are carried out using the Newton-Raphson method to solve in time the listed interrelated nonlinear equations.

Workpiece after modeling induction heating with temperature distribution shown in Fig. 6, goes to the first forging operation (upsetting), as a result of modeling of which a «pancake» is formed with the temperature distribution shown in Fig. 6, $a$. In Fig. 6, $b$, the result of a similar calculation is presented, but for a virtual workpiece with a uniform temperature distribution $T=1140{ }^{\circ} \mathrm{C}$.

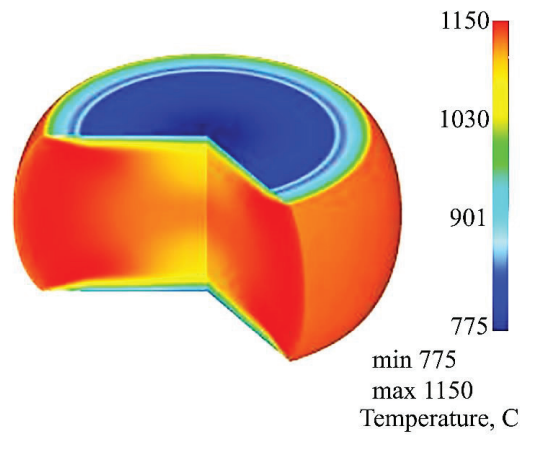

$a$

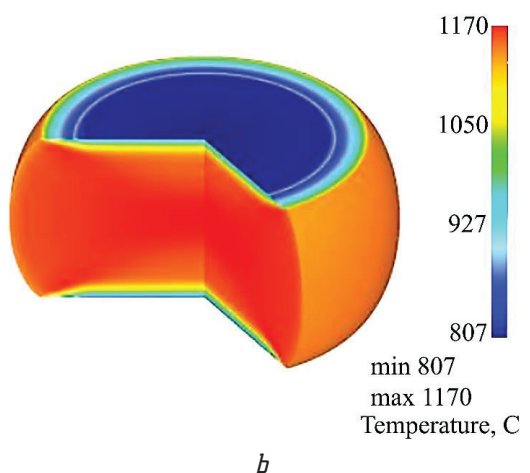

Fig. 6. The distribution of the temperature field in the workpiece after upsetting: $a$ - preliminary uneven temperature distribution; $b-$ preliminary constant temperature distribution

Let's also simulated the time variation of the force required during shaping, depending on the different patterns of temperature distribution over the volume of the workpiece after induction heating. The results of comparison of test calculations with measurements indicate a discrepancy with the experiment of not more than $\pm 15{ }^{\circ} \mathrm{C}$ in the temperature field (which is about $1 \%$ error against the background of maximum temperatures in the range $1140-1190{ }^{\circ} \mathrm{C}$ ) and a discrepancy of $\pm 3 \%$ in effort in the press on the main forging shaping stage in the press. The results of test calculations and their comparison with the full-scale experiment make it possible to consider mathematical FE models and the applied numerical methods as adequate for optimizing design parameters and technological modes with their help.

\section{Research results}

UPEC JEC held a bid among manufacturers of induction heating systems, as well as hydraulic equipment and control systems for press modernization, to develop a modernization project and subsequent manufacture of components for the new forging line. This bid was won by two Czech companies: Roboterm spol. s.r.o. and Hydroma, spol. s.r.o., who proposed their projects for new equipment based on the modeling and preliminary calculations carried out in the work. Refined calculations were performed on designs already developed by the companies named. Fig. 7 shows a three-dimensional solid-state assembly line model developed jointly with Roboterm and Hydroma. Fig. 8 is an assembly drawing of the new Roboterm induction heating line. 
At the end of a two-section inductor, there are two temperature sensors (pyrometers) for adjusting the inductor power and a third sensor for rejecting rings according to the type of burnout or, on the contrary, underheating. As a result of the operation of the feedback control system and the hard-tuned controller, the real picture of power control looked irregular (Fig. 9).

By setting the graph in Fig. 9 changes in the power of the inductor, the dynamics of heating the workpiece is simulated by calculation (Fig. 10).

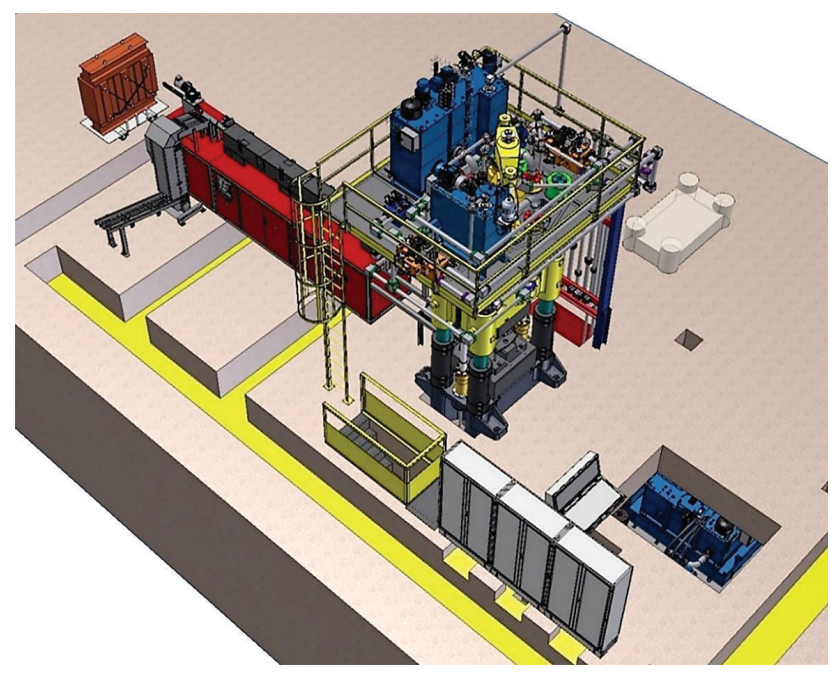

Fig. 7. Three-dimensional solid-state line assembly model

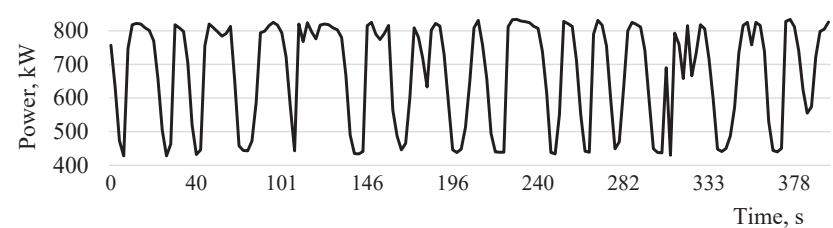

Fig. 9. Inductor control graph

Over the lengths of time that the inductor's power drops to the minimum values, the heat manages to penetrate deep into the workpiece from the peripheral layers, which in turn have time to cool, transferring heat to the inner layers of the material and to the air due to convective and radiation heat transfer. A 4-parameter optimization of inductor control is carried out. The maximum and minimum power and the duration of their retention vary. As an optimization criterion, the conditions of minimum power consumption are accepted. Functional limitations - the temperature on the cylindrical surface of the workpiece is $1160 \pm 10^{\circ} \mathrm{C}$, the temperature in the core of the workpiece is $1080 \pm 10{ }^{\circ} \mathrm{C}$, the temperature spread from the workpiece to the workpiece is not more than $\pm 20{ }^{\circ} \mathrm{C}$.

As a result, let's obtain a graph of the optimal periodic control of the inductor, presented in Fig. 11 and providing a picture of the temperature distribution presented in Fig. 12.

Fig. 13 shows a three-dimensional solid-state model of modernized hydraulic press developed in collaboration with Hydroma company.
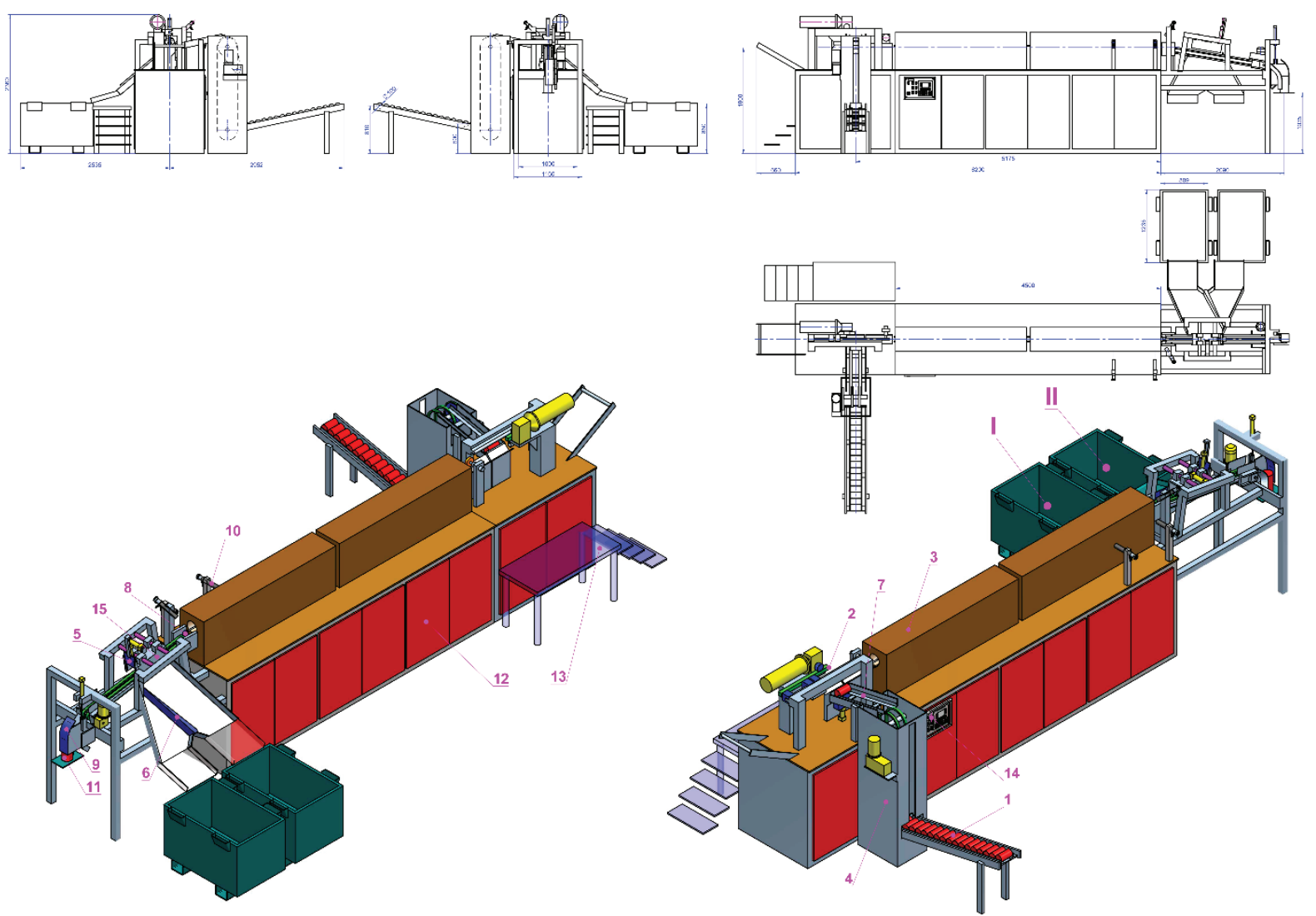

Fig. 8. Assembly drawing of the new Roboterm induction heating line:

1 - input receiver; 2 - pusher; 3 - inductor; 4 - vertical conveyor; 5 - limit switch; 6 - sorter; 7 - connecting receiver;

8 - output roller; 9 - lifting curtain; 10 - pyrometers; 11 - place of unloading of workpieces; 12 - heater body; 13 - platform for maintenance; 14 - control panel; 15 - lever 


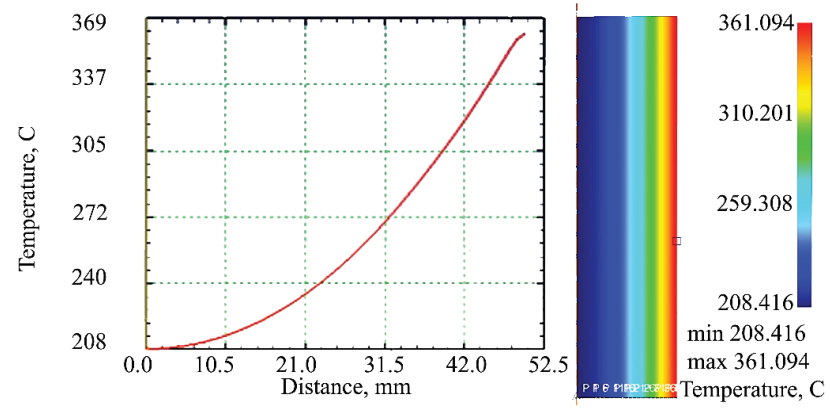

a
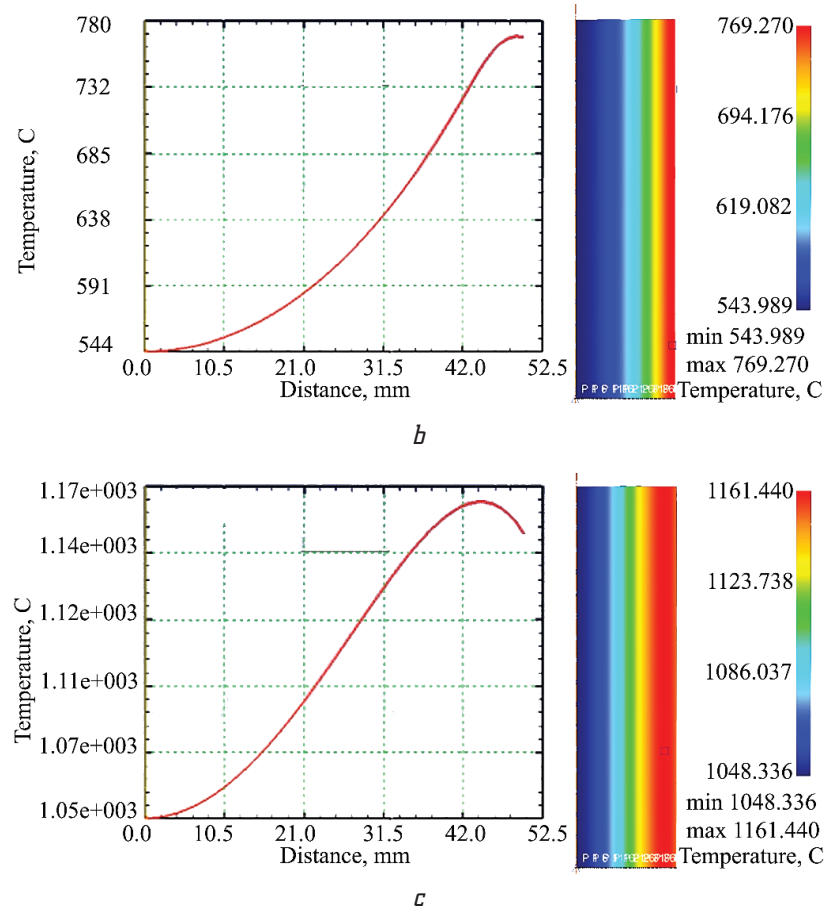

Fig. 10. Temperature distribution in the workpiece (temperature change graph along the radius and temperature field):

$a-25 \%$ of the inductor is passed; $b-50 \%$ of the inductor is passed $c$ - workpiece at the end of the inductor

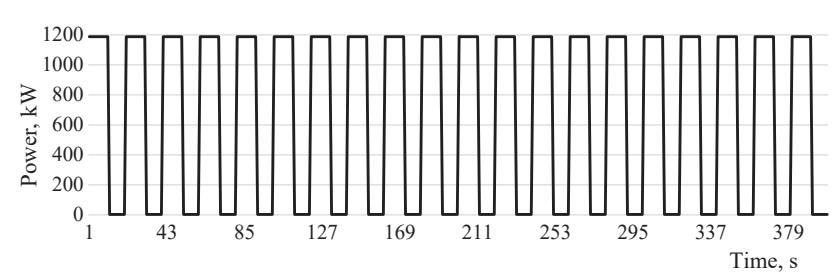

Fig. 11. Graph of optimal periodic inductor control

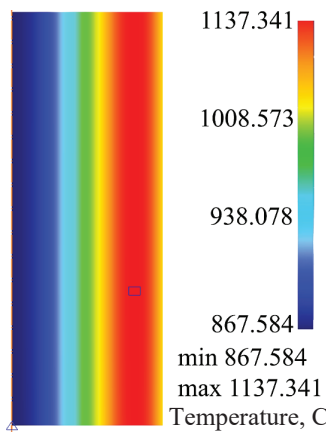

Fig. 12. Temperature distribution pattern

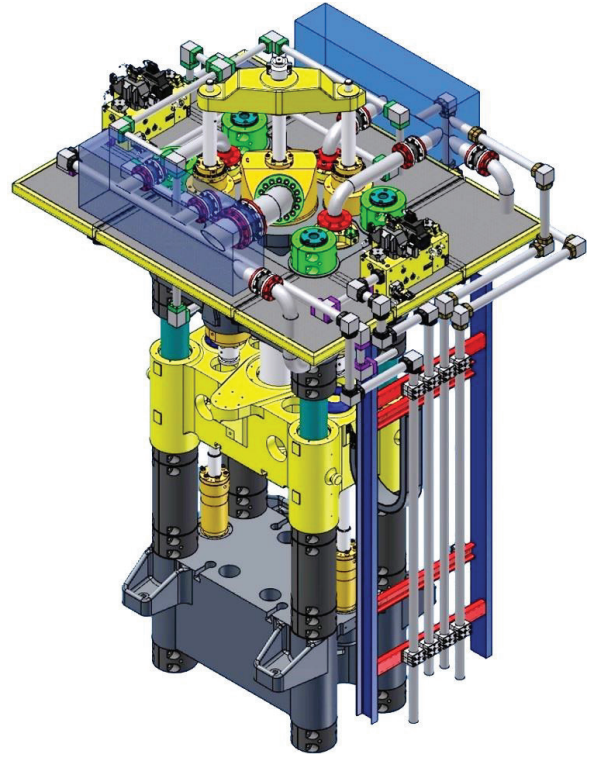

Fig. 13. 3-D solid model of modernized hydraulic press designed together with Hydroma

The new system (Fig. 14) uses the gravitational force of the free fall downstroke, which allows to significantly win in the consumption of total energy in all forging operations (upsetting, shaping, punching), but primarily in combined operations - upsetting and punching.

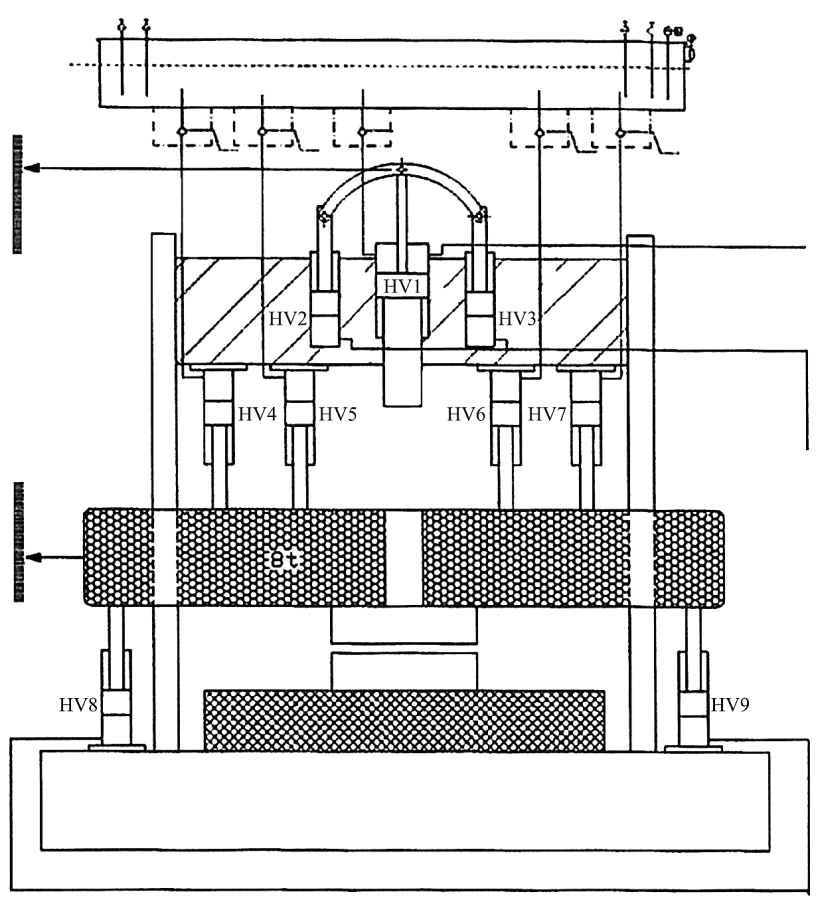

Fig. 14. The hydraulic scheme of the press

In idle mode, the press operates with minimal energy consumption. The idle speed is adjusted using hydraulic control valves. The speed of the gate valves HV2 and HV3 also provides braking of the internal slide.

The maximum idle speed of the traverse and the internal slider is «close» to the speed of free fall. When the kinetic energy of the «falling» internal slider HV1 is exhausted, the valves switch and the hydraulic pump is turned on to complete the shaping operation. 
Similarly, the movement of the traverse for the combined operations «upsetting» and «punching» begins with the help of the kinetic energy of the free fall of the traverse. By opening the valve, the hydraulic oil is sucked from an additional tank located above the press into the hydraulic cylinders HV4+HV5+HV6+HV7. On the HV8 and HV9 hydraulic cylinders hydraulic oil is discharged in to the tank by control. Driving speed is determined by setting the hydraulic valves.

When the kinetic energy of the traverse fall is exhausted, as evidenced by the speed sensor, hydraulic cylinders HV4+HV5+HV6+HV7 during closing of filling valve have simultaneous switch on of pump, providing supply of hydraulic oil and, accordingly, necessary pressure.

Fig. 15 shows the results of modeling the first two forging operations (upsetting and shaping) in the form of a force time graph. In Fig. 15, $b-e$ depict calculations of the shape of the workpiece during different phases of plastic deformation, from the starting state of the workpiece before the beginning of the force application (Fig. 15, b) to the end close to shaping (Fig. 15, f).

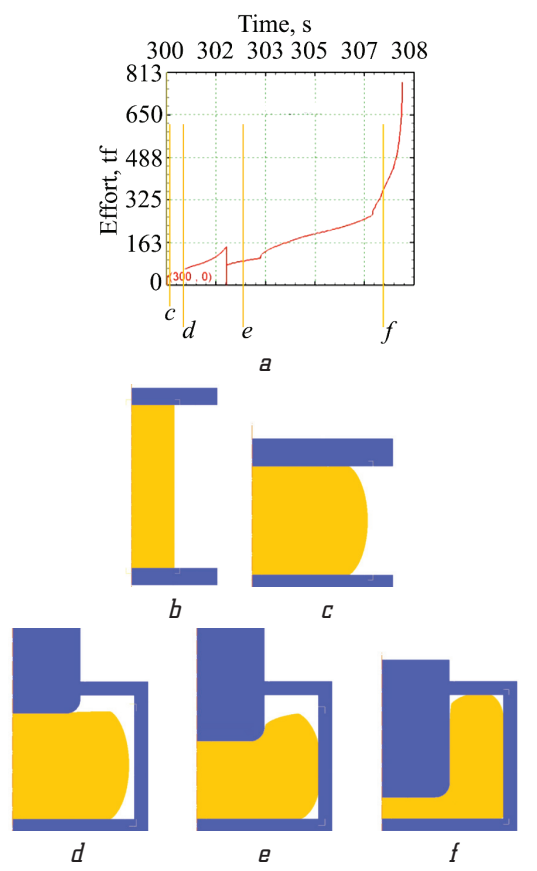

Fig. 15. The results of modeling the first two forging operations (upsetting and shaping) in the form of a "force-time» graph: a - dependence of the force developed by the press on time; $b-e-$ preform shapes during different phases of plastic deformation

It is established that the heating provided by the Roboterm KIN with a surface temperature of $1120{ }^{\circ} \mathrm{C}$ and an even more than $100{ }^{\circ} \mathrm{C}$ colder «core» of the workpiece gives an unacceptable picture of shaping with defective «under-shaping» in the upper corners of the mold. Fig. 16 presents the results of under-shaping of the workpiece:

- for heating the Roboterm KIN and the standard force of the Hydroma press during shaping up to 600 tons (Fig. 16, a);

- for the «ideal» heating of the workpiece to $1160{ }^{\circ} \mathrm{C}$ over its entire volume and maximum effort of 600 tons (Fig. 16, b);

- for «ideal» heating of the workpiece to $1160{ }^{\circ} \mathrm{C}$ over its entire volume and forced force of 730 tons (Fig. 16, c).
Fig. 17 shows a picture of the cooling of a workpiece during three successive forging operations.

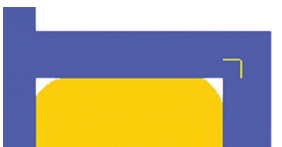

a $b$

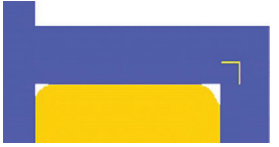

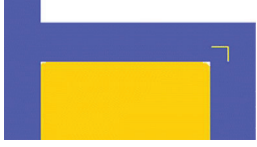

Fig. 16. The results of under-shaping of the workpiece: $a$ - for heating the induction heating unit and during shaping up to 600 tons; $b$ - for warming up to $1160{ }^{\circ} \mathrm{C}$ and effort of $600 \mathrm{t}$; $c-$ for warming up to $1160{ }^{\circ} \mathrm{C}$ and effort of $730 \mathrm{t}$
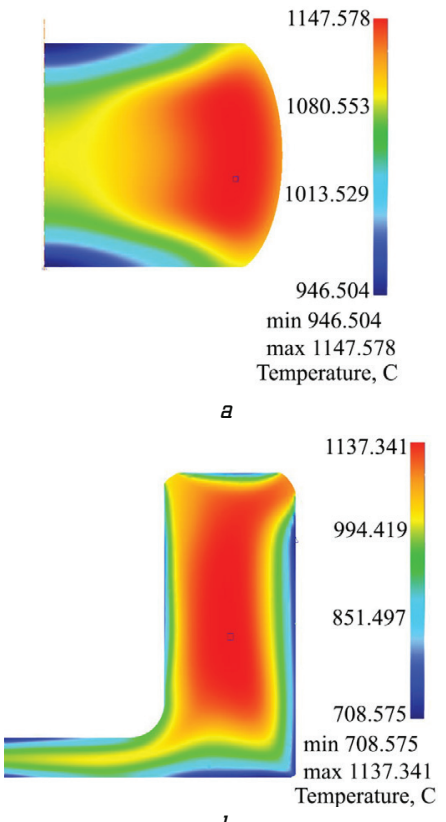

$b$

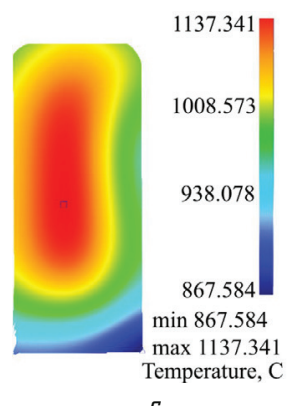

Fig. 17. The results of cooling the workpiece during forging operations: $a$ - upsetting, $b$ - shaping, $c$ - punching

As can be seen from the above results of cooling the workpiece, the maximum temperature of the workpiece after stamping is $1137^{\circ} \mathrm{C}$, the minimum is $708^{\circ} \mathrm{C}$, which is an acceptable result. Therefore, the calculated heating of the workpiece to $1160{ }^{\circ} \mathrm{C}$ is enough to complete the entire cycle of shaping operations.

\section{SWOT analysis of research results}

Strengths. As a result of the study, including mathematical modeling, constructive 3-dimensional design, manufacturing and a large cycle of test and full-scale experiments, it can be argued that the newly developed equipment has such strengths:

1. KIN Roboterm induction heating system has an increased efficiency compared to the previously existing KIN 750 
induction heating line, since it is based on a modern element base and equipped with an electronic thyristor energy converter instead of an electromechanical one.

2. The thyristor converter, by virtue of its device, is automatically tuned to the resonant frequency of the inductor, which greatly reduces the reactive component of power, and thus reduces the energy consumption;

3. The PLC-based control system provides the ability to programmatically control the heating power over a wide range.

4. The modernization of the press with an autonomous pump station with a capacity of $132 \mathrm{~kW}$ (instead of a central station with a capacity of $900 \mathrm{~kW}$ ), as well as the use of the kinetic energy of the slider and traverse, result in a radical reduction in energy consumption. Especially in the conditions of work of several or even more than one of the six forging lines L-408.

Weaknesses. However, the new equipment also has a number of disadvantages, among which the most important:

1. An inductor made of two equal halves in length is controlled by a single control system. Thus, KIN does not have the ability to set different heating power in halves, as is done in equipment with accelerated heating. This design feature does not allow to obtain the maximum effect on saving energy consumption and uniform heating of the workpiece;

2. The controller of the control system is set up by Roboterm in such a way that it only works correctly to maintain the stability of heating of the outer layer of the workpieces at $1120 \pm 20{ }^{\circ} \mathrm{C}$. This is not enough for the press to work without defects due to under-shaping and subsequent high-quality hot rolling.

3. As a result of mathematical modeling, it is proved that the power of one hydraulic pump at the shaping stage is not enough to complete all three forging operations with a total cycle of $18 \mathrm{~s}$. On many workpieces, the upper edges remain unformed. In addition, longer than necessary according to the target sequence diagram, the stay of the workpiece in the form leads to its cooling and scrap at the next stage of rolling.

Opportunities. As tasks for further research, which will improve the productivity of the line and improve the quality of products, it is possible to distinguish 2 areas:

1. Setting up the existing KIN control system for maximum approximation to the target surface temperature indices of $1170 \pm 15{ }^{\circ} \mathrm{C}$, core temperature not less than $1120{ }^{\circ} \mathrm{C}$, cycle time $15 \mathrm{~s}$. The above change in the settings of the KIN control system will allow to reduce the percentage of under-shaped workpieces due to underheating.

2. Setting up the press control system in such a way as to ensure a rapid increase in the shaping force during the last 1-1.5 $\mathrm{s}$ of the shaping stage. In this way, it is possible to achieve compliance with the residence time of the workpiece in the form necessary according to the target cyclogram value. And therefore, to reduce the percentage of defects due to underheating in the subsequent rolling operation.

The best indicators of energy efficiency, productivity and quality of products can be achieved by modernizing the developed equipment. For the induction heating unit, it consists in introducing separate control of the inductor halves, as is done in units with accelerated heating, manufactured by ISR, Inductoheat, GH Induction, EFD and others. For the press, modernization consists in installing an additional hydraulic pump and a hydraulic accumulator (booster), which increase the pressure of the press at the final stage of shaping. The described measures will require significant investments, which will significantly increase the price of a typical modernization of L- 408 forging lines, so the modernization should be preceded by an analysis of the feasibility and effectiveness of the above work.

Threats. The authors of this work suggest that the total cost of old equipment and modernization work will be higher than the cost of purchasing completely new equipment with high energy efficiency, productivity and product quality. In this case, the forging line modernization project will have to be recognized as economically inexpedient.

\section{Conclusions}

1. To simulate induction heating, a mathematical model of induction heating is used, consisting of Maxwell's systems of equations for describing the electromagnetic field and non-stationary Fourier equations of heat conduction. Based on it, a simulation finite element model of a workpiece made of ShKh15 steel with a length of $190 \mathrm{~mm}$ and a radius of $50 \mathrm{~mm}$, placed in a two-section inductor with a current frequency of $800 \mathrm{~Hz}$ in it, is created. The simulation of heating is carried out, the temperature distribution inside the workpiece is obtained. It is found that after the end of the heating operation, the areas with the maximum temperature are located not on the surface of the workpiece, but on its subsurface layers, the temperature difference of the hottest point and the surface reaches $18{ }^{\circ} \mathrm{C}$. The temperature difference between the surface and the core of the workpiece is $65{ }^{\circ} \mathrm{C}$. To simulate the operation of stamping a ring, a mathematical model of a coupled nonlinear thermo-viscous-plastic problem, taking into account nonlinear physical and geometric relationships, is used. A simulation of the forging operations of a workpiece having a previously determined temperature distribution by volume is carried out. As a result of the simulation, the temperature distribution of the workpiece after forging operations is obtained, and the dependences necessary for shaping the press forces on various temperature distributions of the workpiece after heating are obtained. Based on the simulation results, the target cyclogram of the press is determined.

2. According to the results of calculations and modeling, UPEC JEC together with the firms Roboterm spol. s.r.o. and Hydroma, spol. s.r.o. developed designs of the new induction heating unit KSO 1200/1,2-A30 with a capacity of $1200 \mathrm{~kW}$ and the upgraded press P-2038A. Both units receive a modern control system based on PLC with the necessary set of sensors and actuators. The developed solid-state equipment models make it possible to quickly assemble the line from new and existing line equipment.

3. A series of simulation and full-scale experiments of induction heating and stamping of the workpiece is carried out. After comparing the results, the difference in temperature field is not more than $\pm 15{ }^{\circ} \mathrm{C}$ (which is about $1 \%$ error). According to the efforts in the press at the main forging stage of shaping, a difference of $\pm 3 \%$ is obtained. Four parametric optimization of inductor control is carried out, the conditions for minimum power consumption are adopted as an optimization criterion, and the optimal schedule for controlling the heating power is obtained. It is found that after heating the workpiece with 
Roboterm KIN, the surface temperature is $\approx 1160{ }^{\circ} \mathrm{C}$, the temperature difference between the core and the surface reaches $90{ }^{\circ} \mathrm{C}$. It is established that the temperature difference between the core and the surface of the workpiece of the order of $100{ }^{\circ} \mathrm{C}$ or more leads to an unacceptable pattern of shaping with defective «under-shaping» in the upper corners of the die.

As follows from the results of the SWOT analysis, at the moment, not all modernization targets have been achieved by the current Roboterm KIN versions and the Hydroma press hydraulic system.

\section{Acknowledgments}

The authors are grateful to Mr. Richard Fojtik for his help in conducting the experiments.

\section{References}

1. Nemkov, V. S., Demidovich, V. B. (1988). Teoriia i raschet ustroistv indukcionnogo nagreva. Leningrad: Energoatomizdat, 279.

2. Kuvaldin, A. B. (1988). Indukcionnii nagrev ferromagnitnoi stali. Moscow: Energoatomizdat, 198.

3. Elshin, V. V., Zhilcov, Iu. V. (2011). Modelirovanie processa indukcionnogo nagreva $s$ ispolzovaniem programmnogo kompleksa ANSYS. Sovremennye tekhnologii. Sistemnii analiz. Modelirovanie, 1-5. Available at: https://cyberleninka.ru/article/n/ modelirovanie-protsessa-induktsionnogo-nagreva-s-ispolzovaniemprogrammnogo-kompleksa-ansys

4. Zabett, A., Mohamadi Azghandi, S. H. (2012). Simulation of induction tempering process of carbon steel using finite element method. Materials E Design (1980-2015), 36, 415-420. doi: http://doi.org/10.1016/j.matdes.2011.10.052

5. Grozenok, E. D., Simson, E. A., Stepuk, A. V., Shergin, S. Y. (2016). Numerical simulation of the workpieces' temperature field for manufacturing bearing rings during induction heating. Bulletin of the National Technical University «KhPI» Series: Dynamics and Strength of Machines, 26, 50-53. doi: http:// doi.org/10.20998/2078-9130.2016.26.79927

6. Drobenko, B., Hachkevych, O., Kournyts'kyi, T. (2007). A mathematical simulation of high temperature induction heating of electroconductive solids. International Journal of Heat and Mass Transfer, 50 (3-4), 616-624. doi: http://doi.org/10.1016/ j.ijheatmasstransfer.2006.07.013
7. Díaz Moreno, J. M., García Vázquez, C., González Montesinos, M. T., Ortegón Gallego, F. (2012). Analysis and numerical simulation of an induction-conduction model arising in steel heat treating. Journal of Computational and Applied Mathematics, 236 (12), 3007-3015. doi: http://doi.org/10.1016/j.cam.2011.04.007

8. Clain, S., Rappaz, J., Swierkosz, M., Touzani, R. (1993). Numerical modeling of induction heating for two-dimensional geometries. Mathematical Models and Methods in Applied Sciences, 3 (6), 805-822. doi: http://doi.org/10.1142/s0218202593000400

9. Vollrath, D.-I. K. (2013). Simulation of forging processes, Forging Industry Information Service. Industrieverband Massivumformung e. v., 63.

10. Shirgaokar M., Ngaile G., Shen G. (2005). Process Modeling in Impression-Die Forging Using Finite-Element Analysis. Cold and Hot Forging: Fundamentals and Applications, 16, 193-200.

11. Avtonomova, L. V., Grozenok, E. D., Simson, E. A., Stepuk, A. V. (2017). Modelirovanie processa obemnoi shtampovki podshipnikovogo kolca. Visnik NTU «KHPI». Transportne mashinobuduvannia, 14, 135-139.

12. Basic, H., Duharkic, M., Burak, S. (2019). Numerical simulation of hot forging process in production of axisymmetric automobile parts. Periodicals of Engineering and Natural Sciences (PEN), 7 (4), 1572-1581. doi: http://doi.org/10.21533/pen.v7i4.487

13. Behrens, B.-A. (2008). Finite element analysis of die wear in hot forging processes. CIRP Annals, 57 (1), 305-308. doi: http:// doi.org/10.1016/j.cirp.2008.03.087

14. L-Cancelos, R., Varas, F., Martín, E., Viéitez, I. (2016). Analysis of the thermo-mechanical deformations in a hot forging tool by numerical simulation. IOP Conference Series: Materials Science and Engineering, 119, 012021. doi: http://doi.org/10.1088/ $1757-899 \mathrm{x} / 119 / 1 / 012021$

15. Aydı, M., Kisioglu, Y. (2013). Hydraulic press design under different loading conditions using finite element analysis. Engineering Science and Technology, 16, 129-138.

Girshfeld Anatoliy, Corr.-member, Engineering Academy of Ukraine, President, Private Joint Stock Company «U.P.E.C.», Kharkiv, Ukraine, ORCID https://orcid.org/0000-0002-3759-7280

Simson Eduard, Doctor of Technical Sciences, Professor, Laureate of the National Award in the field of science and technology, Honored Scientist of Ukraine, Academic of Engineering Academy of Ukraine, Department of Continuum Mechanics and Resistance of Materials, National Technical University «Kharkiv Polytechnic Institute»,Ukraine, e-mail: prof.simson@gmail.com, ORCID: https:// orcid.org/0000-0003-4178-4828 